\title{
Toxic Action of Aqueous Wheat Straw Extract on Horse PURSLANE ${ }^{1}$
}

\author{
Ação Tóxica do Extrato Aquoso da Palha de Trigo sobre Beldroega Cavalo
}

KHALIQ, A..$^{*}$, MATLOOB, A. ${ }^{2}$, ASLAM, F. ${ }^{2}$, MUSHTAQ, M.N. ${ }^{3}$ and KHAN, M.B. ${ }^{4}$

\begin{abstract}
The toxic action of aqueous wheat (Triticum aestivum) straw extracts was investigated on germination, early seedling growth, some biochemical attributes and the antioxidant enzymes of horse purslane (Trianthema portulacastrum). Aqueous extracts of wheat straw were prepared by soaking the wheat straw in distilled water in $1: 10 \mathrm{w} / \mathrm{v}$ ratio and diluted to obtain the concentrations of $0,25,50,75$ and $100 \%$. These were used as pre and post emergence in laboratory and screen house trials. Wheat aqueous extracts exhibited phytotoxicity to horse purslane by inhibiting and delaying its germination and suppressing seedling growth. Wheat phytotoxins in its aqueous extracts suppressed the chlorophyll content and soluble protein, and enhanced soluble phenolics and the activity of antioxidant enzymes as catalase, peroxidase and superoxide dismutase in the seedlings of horse purslane compared with the control. Such inhibitory activity is believed to originate from exposure to wheat phytotoxins that are present in its aqueous straw extract. The suppressive effects of wheat straw need to be investigated further under field conditions.
\end{abstract}

Keywords: phytotoxins, germination, seedling growth, phenolics, antioxidants.

RESUMO - A ação tóxica de extratos aquosos da palha de trigo (Triticum aestivum) foi investigada na germinação, no crescimento inicial da plântula, em alguns atributos bioquimicos e nas enzimas antioxidantes de beldroegas-cavalo (Thianthema portulacastrum). Extratos aquosos de palha de trigo foram preparados pela imersão deste em água destilada na proporção de 01:10 m/v e diluidos para obtenção de cinco concentrações (0, 25, 50, 75 e 100\%). Estes foram usados como pré e pós-emergência em ensaios de laboratório e casa de vegetação. Os extratos aquosos de trigo exibiram toxicidade às beldroegas-cavalo, inibindo e retardando a sua germinação e suprimindo o crescimento das plântulas. Toxinas no extrato aquoso de trigo suprimiram o teor de clorofila e proteina solúvel, aumentaram os fenóis solúveis e a atividade de enzimas antioxidantes como catalase, peroxidase e superóxido dismutase em plântulas de beldroega-cavalo comparado ao controle. Acreditase que essa atividade inibitória origina-se da exposição das beldroegas-cavalo às toxinas presentes no extrato aquoso de palha de trigo. Efeitos supressivos da palha de trigo precisam serinvestigados em condições de campo.

Palavras-chave: palha de trigo, toxinas, germinação, crescimento das plântulas, fenólicos antioxidantes.

\section{INTRODUCTION}

Allelopathy explains the inhibitory and stimulatory interactions in the soil-plant interface through biochemical pathways. It has been acknowledged as a stress factor and has been assimilated to the process and effect. In agricultural practice, plants showing detrimental allelopathic effects can be exploited for pest and weed control (Tesio \& Ferrero, 2011). The phenomenon plays an important role by influencing

1 Recebido para publicação em 10.8.2011 e aprovado em 7.3.2012.

2 Department of Agronomy, University of Agriculture, Faisalabad, Pakistan; ${ }^{3}$ Graduate School of Life and Environmental Sciences, University of Tsukuba, Tsukuba 305-8572, Ibaraki, Japan; ${ }^{4}$ Department of Agronomy, University College of Agriculture, B.Z.U, Multan, Pakistan, <khaliquaf@gmail.com>. 
processes such as diversity, succession, and invasion (Chou, 1999) by modifying soil environments. Several plants produce and accumulate potentially phytotoxic compounds called "allelochemicals" in their tissues that can suppress neighboring plants (Weston $\&$ Duke, 2003). Allelochemicals can interfere with the basic processes of receiver plants such as photosynthesis, cell division, respiration and protein synthesis (Duke \& Dayan, 2006) and indirectly provoke other forms of stress. Another profound effect of these allelochemicals is the activation of the cellular antioxidant system in response to uncontrolled production and the accumulation of reactive oxygen species (Bogatek \& Gniazdowska, 2007).

Wheat (Triticum aestivum) is a potential allelopathic plant and its phytotoxic activity has been attributed to hydroxamic acids and related compounds (Wu et al., 2000a; Villagrasa et al., 2006) as well as phenolic acids (Wu et al., 2001). Wheat aqueous extracts were also allelopathic to pitted morning glory (Ipomoea lacunosa), common ragweed (Ambrosia artemisiifolia), and also to herbicide susceptible and resistant biotypes of annual ryegrass (Lolium rigidum) (Liebl \& Worsham, 1983; Wu et al., 2000b, Wu et al., 2001). Wheat straw can furnish selective weed control either through the release of water soluble allelochemicals upon decomposition or due to its physical presence on the soil surface thus shading and altering the red to far red ratio of transmitted light (Bhowmik \& Inderjit, 2003). Several factors are known to influence the magnitude of allelopathic activity, i.e., the donor/receiver (biological response capacity) species, tissue concentration of bioactive compounds, duration of cover, soil texture, substratum ecology, microbial population and nutrient dynamics.

Bioassays are often carried out for the estimation of the potency of a compound via its application induced response and are an essential component of allelopathic research. Bioassay studies are widely used as early proof of allelopathic activity owing to the low cost involved, easy execution and replication (Inderjit \& Weston, 2000). The most commonly used bioassay technique is to evaluate the influence of allelopathic extract on the germination and seedling growth of the test species. However, contrary to bioassays, the suppression achieved under field conditions is often negligible (Duke et al., 2001), and studies have demonstrated contrasting results under controlled and natural conditions (Inderjit \& Weston, 2000). It is not practically possible to simulate the exact field conditions in a bioassay, but an effort is made in present studies by using soil as a growing medium that helps maintain the physical, chemical, and biological factors of the natural setting, as soil possesses the ability to detoxify allelochemicals (Blum et al., 1999). Inderjit $\&$ Weiner (2001) asserted that in order to achieve a better understanding of the subject matter, allelopathy should be conceptualized in terms of soil ecology.

Horse purslane (Trianthema portulacastrum) is an annual native plant of South Africa with wide distribution across South East and West Asia, Africa and Tropical America (Bolivia, Brazil, Peru, Ecuador, Panama, Venezuela and Guatemala). It is a pernicious terrestrial weed that infests major field crops such as pulses, cotton, sugarcane, direct seeded rice and maize during the summer season in the Indo-Pak region, and is highly competitive due to the $\mathrm{C}_{4}$ carbon fixation pathway. Wheat is the main winter crop grown throughout the Indo-Pak region, and is followed in rotation by almost all of the above summer crops. Information on the allelopathic effect of wheat on horse purslane remains scarce. The present study aims at investigating the allelopathic activity of aqueous wheat straw extracts that are applied as a pre or post emergence application on the dynamics of horse purslane germination and its seedling growth in laboratory and screen house conditions. Some biochemical attributes regarding aqueous wheat extracts and horse purslane were also worked out.

\section{MATERIAL AND METHODS}

\section{Preparation of extracts}

Field grown mature wheat ( $c v$. Sehar-2006) plants were harvested at maturity during the 2008-09 growing season and dried under shade. These were chopped with an electric 
fodder cutter into $2-3 \mathrm{~cm}$ pieces and dried in an oven at $70{ }^{\circ} \mathrm{C}$ for $48 \mathrm{~h}$. The oven-dried material was ground and passed through a 40-mesh screen. Ground herbage was soaked in distilled water $(1 \mathrm{~g}$ per $10 \mathrm{~mL})$ for $24 \mathrm{~h}$ at ambient temperature $\left(25{ }^{\circ} \mathrm{C} \pm 2\right)$. The extract was obtained by filtering the mixture through a Whattman \# 42 filter paper. This filtrate was designated as a stock solution for the aqueous extract of wheat having $100 \%$ concentration. It was used either as such or diluted with distilled water for making the desired concentrations. The $\mathrm{pH}$ and electrical conductivity of these extracts were determined with the help of digital $\mathrm{pH}$ and conductivity meters (HI-9811, Hannah, USA). The osmotic potential of different extract concentrations was determined using the formula:

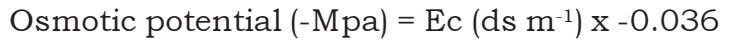

Total water-soluble phenolics were determined as per Swain and Hillis (1959) using Folin-cicalteu reagent and are expressed as vanillic acid equivalents as it has been found as an allelochemical in wheat straw (Lodhi et al., 1987). The chemical characteristics of the extract are given in Table 1 .

\section{Experiment-I: Influence of aqueous wheat extract at different concentrations on the seed germination of horse purslane}

Horse purslane seeds were collected and cleaned manually to ensure physical purity. These seeds were surface sterilized with a water:bleach solution (10:1) for 15 minutes and rinsed with distilled water four times. These seeds were placed evenly between two layers of moist Whattman No. 42 filter paper in sterilized Petri dishes. Aqueous wheat extract (100\%) was diluted with distilled water to prepare solutions of 25,50 , and $75 \%(\mathrm{v} / \mathrm{v})$ concentrations. The extract of the respective concentration $(5 \mathrm{ml})$ was added to each Petri dish while the same volume of distilled water was applied in the control treatment. Half of the solution was used as moisture for the filter paper receiving the seeds, while the remaining was applied to the covering filter paper.

Germination counts were recorded on a daily basis according to AOSA (1990) until a constant count was achieved. The seeds were considered to be germinated when the radicle and hypocotyl lengths were over $2 \mathrm{~mm}$. The time taken up to $50 \%$ emergence of the seedlings $\left(\mathrm{E}_{50}\right)$ was calculated according to the modified formulae of Farooq et al. (2005):

$$
E_{50}=t_{i}+\frac{\left(\frac{N}{2}-n_{i}\right)\left(t_{j}-t_{i}\right)}{n_{j}-n_{i}}
$$

where $N$ is the final number of the emerged seeds, and $n_{i}$ and $n_{j}$ are the cumulative number of seeds emerged by adjacent counts at times (days) $t_{i}$ and $t_{j}$ where $n_{i}<N / 2<n_{j}$. The mean emergence time (MET) was calculated according to Ellis \& Robert (1981):

$$
M E T=\frac{\sum D n}{\sum n}
$$

where $n$ is the number of seeds, which were emerged on day $D$, and $D$ is the number of days counted from the beginning of emergence. The Emergence Index (EI) was calculated as described by AOSA (1983):

Table 1 - Characteristics of different concentrations of aqueous wheat straw extract

\begin{tabular}{|c|c|c|c|c|}
\hline $\begin{array}{c}\text { Aqueous wheat straw } \\
\text { extract concentration } \\
(\%)\end{array}$ & $\mathrm{pH}$ & $\begin{array}{c}\mathrm{Ec} \\
\left(\mathrm{dS} \mathrm{m}^{-1}\right)\end{array}$ & $\begin{array}{c}\text { Osmotic potential } \\
(-\mathrm{Mpa})\end{array}$ & $\begin{array}{c}\text { Total soluble phenolics } \\
\left(\mu \mathrm{gL}^{-1}\right)\end{array}$ \\
\hline 25 & 6.75 & 0.245 & 0.009 & 113.38 \\
\hline 50 & 6.52 & 0.323 & 0.011 & 257.65 \\
\hline 75 & 6.36 & 0.478 & 0.017 & 461.73 \\
\hline 100 & 6.18 & 0.521 & 0.018 & 638.33 \\
\hline
\end{tabular}




$$
E I=\frac{\text { No. of emerged seeds }}{\text { Days of first count }}+-----+\frac{\text { No. of emergec }}{\text { Days of final }}
$$

\section{Experiment - II: Influence of the aqueous wheat extract at a different concentration on morphological and biochemical attributes of horse purslane seedling}

\section{Seed bioassays in pots}

Plastic pots measuring $29 \times 18 \mathrm{~cm}(10 \mathrm{~kg})$ were filled with air dried and well mixed field soil collected from the Agronomic Research Area. The soil belongs to the Lyallpur soil series (Aridisol-fine-silty, mixed, hyperthermic Ustalfic, Haplargid in USDA classification, and Haplic Yermosols in FAO classification). The $\mathrm{pH}$ of the saturated soil paste and electrical conductivity of the saturation extract were 7.6 and $0.41 \mathrm{dS} \mathrm{m}^{-1}$, respectively. Twenty horse purslane seeds were sown in each pot, and 15 seedlings were maintained before treatment application. The pots were placed in a screen house under natural conditions with a 14/ 10 h light/dark photoperiod. The pots were irrigated as and when required in order to avoid water stress.

Aqueous wheat extract at concentrations of $25,50,75$ and $100 \%(\mathrm{v} / \mathrm{v})$ were foliar applied as a post-emergence spray using a hand operated sprayer at 2-4 leaf stage. Volume of spray (300 L ha-1) was calibrated using water. The number of leaves, nodes and lateral branches on each seedling were counted two weeks after the foliar application of the aqueous wheat extracts. Thereafter, the seedlings were uprooted and the secondary roots were counted manually and averaged. Root and shoot lengths were measured with a measuring tape. The seedling roots and shoots from each pot were clipped separately, and oven dried at $70{ }^{\circ} \mathrm{C}$ for $48 \mathrm{~h}$ to obtain the dry biomass of root and shoot; total seedling biomass of the seedling was calculated as the sum of the biomass of root and shoot. A sub-sample of $2 \mathrm{~g}$ leaves was used to measure the leaf area using a Leaf Area Meter (Licor, Model LI-3000).

\section{Biochemical analyses}

About two weeks after the foliar application of treatments, fresh tissue biomass was harvested and used for the determination of total soluble phenolics as described by Randhir $\&$ Shetty (2005), and was expressed as gallic acid equivalents. Photosynthetic pigments (Chl. a and Chl. b) were extracted in $80 \%$ ice cold acetone and read out at 663 and $645 \mathrm{~nm}$ wavelength in a UV-spectrophotometer (UV4000, ORI, Germany). These are expressed as $\mathrm{mg} \mathrm{g}^{-1}$ fresh leaf weight (Lichtenthaler $\&$ Wellburn, 1987). Soluble proteins were measured per Bradford (1976) using crystalline bovine albumin as a reference. Superoxide dismutase (SOD) activity was calculated as described by Giannopotitis \& Ries (1977) at $560 \mathrm{~nm}$. One unit of SOD activity was defined as the amount of enzyme inhibiting the photochemical reduction of NBT by $50 \%$ per minute. Catalase (CAT) activity based on the consumption of $\mathrm{H}_{2} \mathrm{O}_{2}$ was determined using the method of Dhindsa et al. (1981). The consumption of $\mathrm{H}_{2} \mathrm{O}_{2}$ was observed at $240 \mathrm{~nm}$ and one unit of CAT was defined as the amount of enzyme required to oxidize $1 \mu \mathrm{M} \mathrm{H}_{2} \mathrm{O}_{2}$ min $^{-1}$. Peroxidase (POX) activity was recorded as described by Egley et al. (1983). The increase in absorbance due to guaiacol oxidation was measured at $470 \mathrm{~nm}$. One unit of enzyme activity was defined as the amount of enzyme required to oxidize $1 \mu \mathrm{M}$ guaiacol $\mathrm{min}^{-1}$.

\section{Experimental design and statistical analysis}

All the experiments were conducted using a completely randomized design with five replications. Following the Fisher's analysis of variance technique (Steel et al., 1997), the mean values were separated using least significant differences (LSD) at $\mathrm{P}<0.05$ using the computer statistical program MSTAT-C (Freed \& Scott, 1986).

\section{RESULTS AND DISCUSSION}

\section{Experiment - I: Influence of aqueous wheat extract at different concentrations on the germination of horse purslane}

Aqueous wheat extracts at different concentrations delayed the time to the start of 
germination (TSG) and 50\% emergence (E50) of horse purslane (Table 2). The delay in TSG was insignificant at a lower extract concentration $(25 \%)$ but rose to a significant level $(\mathrm{P} \leq 0.05)$ beyond this concentration. Nonetheless, TSG and E50 did not vary among the 50, 75 and $100 \%$ extract concentrations. TSG and E50 were almost doubled at an aqueous extract concentration of $100 \%$. A similar trend was observed for the mean emergence time, so that it was prolonged only at an aqueous extract concentration beyond $25 \%$. Increased values of MET (32-38\%) relative to the control indicated that not only germination was delayed but its events were also not synchronized. Such a delay in the seed germination of any weed species can have important ecological implications by affecting the seedling establishment (Escudero et al., 2000; Chaves et al., 2001), and their chances of competing for resources with neighboring species (Xingxinag et al., 2009). Such effects lead ultimately to an overall decline in the density, vigor and stand establishment of the weeds (Gallandt et al., 1999). Increasing aqueous extract concentration exhibited significant inhibition in final germination only when applied at a concentration beyond $25 \%$, and the inhibition ranged from 29 to 64\% (Table 1). Emergence indices (EI) of horse purslane were also depressed with an increasing extract concentration and the highest suppression was observed with $100 \%$ extract concentration. The extent of germination inhibition was highly concentration dependent so that increasing the extract concentration had a negative bearing on it (Figure 1A), and the
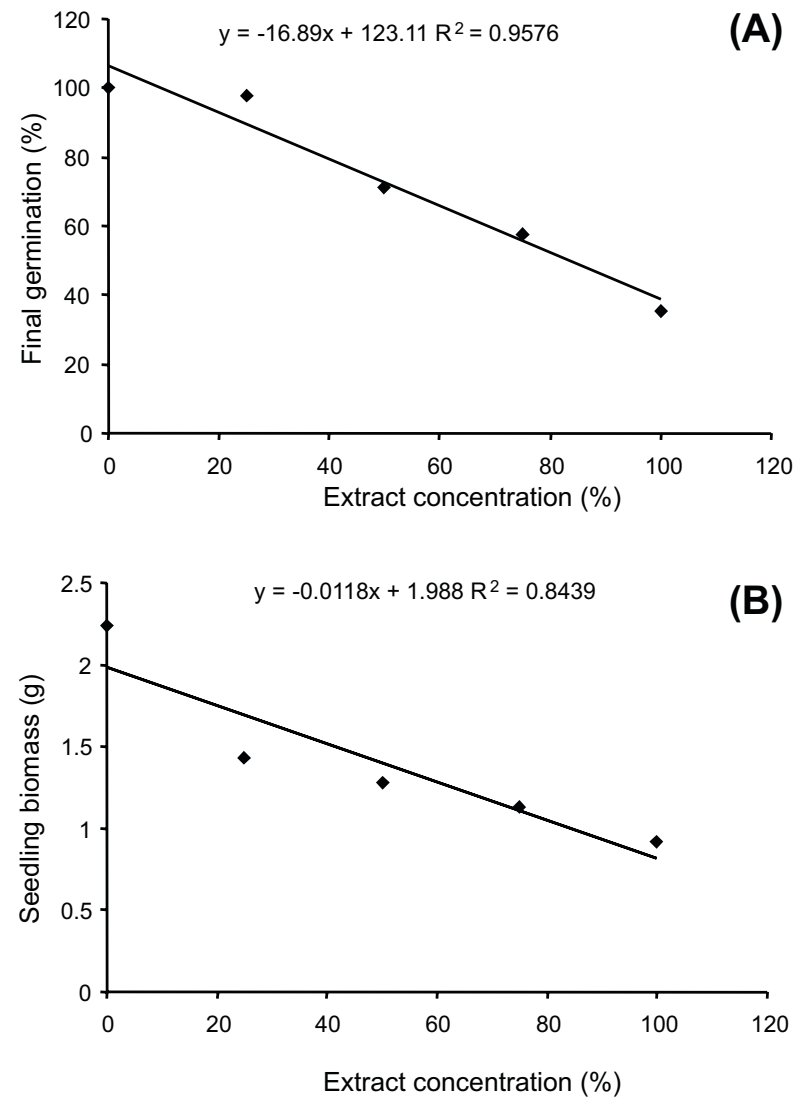

Figure 1 - Relationship between (a) germination and (b) seedling biomass in horse purslane and aqueous wheat straw extract.

Table 2 - Influence of aqueous wheat extract at different concentrations on the germination traits of horse purslane

\begin{tabular}{|c|c|c|c|c|c|}
\hline $\begin{array}{c}\text { Aqueous wheat } \\
\text { straw extract } \\
\text { concentration }(\%)\end{array}$ & $\begin{array}{l}\text { Time to start } \\
\text { germination (days) }\end{array}$ & $\begin{array}{l}\text { Final germination } \\
\qquad(\%)\end{array}$ & $\begin{array}{c}\text { Time to } 50 \% \\
\text { emergence (days) }\end{array}$ & $\begin{array}{l}\text { Mean emergence } \\
\text { time (days) }\end{array}$ & $\begin{array}{c}\text { Emergence } \\
\text { index }\end{array}$ \\
\hline 0 & $3.00 \mathrm{c}^{*}$ & $100 \mathrm{a}$ & $3.97 \mathrm{~b}$ & $5.89 \mathrm{~b}$ & $11.03 \mathrm{a}$ \\
\hline 25 & $\begin{array}{l}4.00 \mathrm{bc} \\
(33) * *\end{array}$ & $\begin{array}{c}97.77 \mathrm{a} \\
(-2)\end{array}$ & $\begin{array}{c}5.40 \mathrm{ab} \\
(36)\end{array}$ & $\begin{array}{c}6.76 \mathrm{~b} \\
(15)\end{array}$ & $\begin{array}{l}7.90 \mathrm{~b} \\
(-28)\end{array}$ \\
\hline 50 & $\begin{array}{c}5.00 \mathrm{ab} \\
(67)\end{array}$ & $\begin{array}{c}71.11 b \\
(-29)\end{array}$ & $\begin{array}{l}5.97 \mathrm{a} \\
(50) \\
\end{array}$ & $\begin{array}{c}7.94 \mathrm{a} \\
(35) \\
\end{array}$ & $\begin{array}{l}5.53 c \\
(-50)\end{array}$ \\
\hline 75 & $\begin{array}{c}5.33 \mathrm{a} \\
(78) \\
\end{array}$ & $\begin{array}{c}57.77 \mathrm{c} \\
(-42) \\
\end{array}$ & $\begin{array}{c}6.44 \mathrm{a} \\
(62) \\
\end{array}$ & $\begin{array}{c}7.81 \mathrm{a} \\
(33) \\
\end{array}$ & $\begin{array}{c}3.47 \mathrm{~cd} \\
(-68)\end{array}$ \\
\hline 100 & $\begin{array}{c}5.67 \mathrm{a} \\
(89)\end{array}$ & $\begin{array}{c}35.55 \mathrm{~d} \\
(-64)\end{array}$ & $\begin{array}{c}7.00 \mathrm{a} \\
(76)\end{array}$ & $\begin{array}{c}8.13 \mathrm{a} \\
(38)\end{array}$ & $\begin{array}{c}1.53 d \\
(-86)\end{array}$ \\
\hline LSD $\mathrm{P} \leq 0.05$ & 1.32 & 12.53 & 1.64 & 1.00 & 2.15 \\
\hline
\end{tabular}

* Means with different letters differ significantly at the $5 \%$ probability level by an LSD test. ** Figures given in parentheses show the percentage change over the control. 
regression accounted for $96 \%$ variation in germination owing to extract concentration. Increased phytotoxicity observed at a higher extract concentration may be attributed to a sequential increase in the concentration of individual phytotoxin or their compound effect. Enhanced phytotoxic effects of different concentrations of aqueous extracts are also reported for Cichorium intybus (Khaliq et al., 2009). Khanh et al. (2005) concluded that the suppression magnitude in allelopathic interactions is directly proportional to the applied dose.

\section{Experiment-II: Influence of aqueous wheat extract at different concentrations on the morphological and biochemical attributes of horse purslane seedling}

Wheat aqueous extract was inhibitory to the seedling growth of horse purslane at all concentrations (Table 3 ) and suppressed the shoot and root length by 43 and $55 \%$ at an extract concentration of $100 \%$. The highest suppression in shoot and root dry weight (58 and 67\%, respectively) was also recorded for the same concentration. The $75 \%$ concentration gave as a good reduction in seedling root biomass as was recorded with a $100 \%$ concentration of the extract. The herbicidal potential of aqueous wheat extracts was also manifested on all seedling traits as leaf score, lateral roots, nodes and lateral branches per plant, which was reflected by their significantly lower values than the control (Table 2). The leaf area remained unaffected by lower extract concentrations (25 and $50 \%$ ) but decreased considerably (9\%) at higher concentrations.

The analysis and interpretation of the data acquired from bioassays studies emphasized the herbicidal potential of wheat against horse purslane. Such an activity is explained by the presence of a number of phytotoxic compounds in wheat. Wheat is a potent source of bioactive phytotoxic compounds representing three main classes as phenolics ( $p$-hydroxybenzoic, vanillic, pcoumaric, syringic and ferulic acids being most frequently reported and transferulic and trans-pcoumaric acids being the dominant acids), cyclic hydroxamic acids (a class of alkaloids) and short chain fatty acids (Wu et al., 2001; Ma, 2005). Most of these allelochemicals are water soluble and can be leached from surface straw by rainfall and imbibed by the germinating weed seeds in the immediate vicinity. Moreover, these can also be absorbed by roots. The present studies demonstrated impaired germination and retarded seedling growth of horse purslane with the application of aqueous wheat extracts (Tables 1-3). These were reflective of allelopathic activity mediated by the presence of such compounds in the aqueous extracts. The suppressive phytotoxic effects of wheat against both grassy and broad leaved weeds are also reported elsewhere (Li et al., 2000; Wu et al., 2002; Mathiassen et al., 2006; Labbafi et al., 2010). The suppression of horse purslane seedling was also higher with increased concentration (Fig. 1B) as depicted by $84 \%$ variation due to the extract concentration.

The total chlorophyll content were lowered by $7,27,40$ and $56 \%$ with $25,50,75$ and $100 \%$ extract concentration and the level of suppression was more pronounced at a higher extract concentration (Table 4). Significantly higher (19-105\%) total soluble phenolics over the control were recorded with the foliar application of aqueous wheat extract at different concentrations. These extract also resulted in lower protein contents and higher activity of antioxidant enzymes over the control (Table 4). Higher extract concentrations amounted to the lowest values of soluble proteins and the highest values of CAT and POX. In contrast to these, SOD activity was decreased at $100 \%$ extract concentration.

Chlorophyll content in the leaves of horse purslane seedlings exposed to aqueous wheat extracts decreased (Table 3). A decrease in the chlorophyll content may have been due to the exposure of the growing seedlings to phytotoxic compounds that are mostly phenolic in nature. Patterson (1981) reported that soybean plants treated with phenolic acids such as ferulic, p-coumaric, and vanillic acids exhibited lower chlorophyll content in leaves. Wheat allelochemicals might have inhibited chlorophyll in horse purslane by interfering with the biosynthesis of photosynthetic pigments or enhancing their degradation by inducing oxidative stress via the generation of reactive oxygen species, or both of these. Reduction in chlorophyll was associated 
Table 3 - Influence of aqueous wheat extract at different concentrations on the seedling growth of horse purslane

\begin{tabular}{|c|c|c|c|c|c|c|c|c|c|c|}
\hline $\begin{array}{c}\text { Aqueous } \\
\text { wheat straw } \\
\text { extract } \\
\text { concentration }\end{array}$ & $\begin{array}{l}\text { Shoot } \\
\text { length }\end{array}$ & $\begin{array}{l}\text { Root } \\
\text { length }\end{array}$ & $\begin{array}{c}\text { Shoot dry } \\
\text { weight }\end{array}$ & $\begin{array}{c}\text { Root dry } \\
\text { weight }\end{array}$ & $\begin{array}{c}\text { Total dry } \\
\text { weight }\end{array}$ & \multirow[t]{2}{*}{$\begin{array}{c}\text { Leaf score } \\
\text { per plant }\end{array}$} & \multirow[t]{2}{*}{$\begin{array}{c}\text { Secondary } \\
\text { roots per } \\
\text { plant }\end{array}$} & \multirow[t]{2}{*}{$\begin{array}{c}\text { Nodes } \\
\text { per plant }\end{array}$} & \multirow[t]{2}{*}{$\begin{array}{c}\text { Lateral } \\
\text { shoots }\end{array}$} & \multirow{2}{*}{$\begin{array}{c}\text { Leaf area } \\
\left(\mathrm{cm}^{2}\right)\end{array}$} \\
\hline$(\%)$ & \multicolumn{2}{|c|}{$(\mathrm{cm})$} & \multicolumn{3}{|c|}{$\left(\right.$ g seedling $\left.^{-1}\right)$} & & & & & \\
\hline 0 & $26.14 \mathrm{a}^{*}$ & $23.98 \mathrm{a}$ & $2.07 \mathrm{a}$ & $0.17 \mathrm{a}$ & $2.24 \mathrm{a}$ & $125.80 \mathrm{a}$ & $21.88 \mathrm{a}$ & $42.17 \mathrm{a}$ & $35.51 \mathrm{a}$ & $149.20 \mathrm{a}$ \\
\hline 25 & $\begin{array}{l}20.05 \mathrm{~b} \\
(-23)^{* *}\end{array}$ & $\begin{array}{c}13.67 \mathrm{~b} \\
(-43)\end{array}$ & $\begin{array}{c}1.33 \mathrm{~b} \\
(-36)\end{array}$ & $\begin{array}{c}0.10 \mathrm{~b} \\
(-40)\end{array}$ & $\begin{array}{c}1.43 \mathrm{~b} \\
(-36)\end{array}$ & $\begin{array}{c}85.83 \mathrm{~b} \\
(-32) \\
\end{array}$ & $\begin{array}{c}17.12 b \\
(-22)\end{array}$ & $\begin{array}{c}22.48 \mathrm{~b} \\
(-47) \\
\end{array}$ & $\begin{array}{c}24.17 \mathrm{~b} \\
(-32)\end{array}$ & \begin{tabular}{|c|}
$156.90 \mathrm{a}$ \\
$(5.14)$ \\
\end{tabular} \\
\hline 50 & $\begin{array}{c}16.30 \mathrm{bc} \\
(-38)\end{array}$ & $\begin{array}{c}13.07 \mathrm{bc} \\
(-54)\end{array}$ & $\begin{array}{c}1.19 b c \\
(-42)\end{array}$ & $\begin{array}{c}0.09 \mathrm{~b} \\
(-48)\end{array}$ & $\begin{array}{c}1.28 b c \\
(-43)\end{array}$ & $\begin{array}{c}79.70 \mathrm{c} \\
(-37)\end{array}$ & $\begin{array}{c}11.18 \mathrm{~d} \\
(-49)\end{array}$ & $\begin{array}{c}19.08 \mathrm{c} \\
(-55)\end{array}$ & $\begin{array}{c}18.00 \mathrm{c} \\
(-49)\end{array}$ & \begin{tabular}{|c|}
$153.40 \mathrm{a}$ \\
$(2)$
\end{tabular} \\
\hline 75 & $\begin{array}{c}14.74 \mathrm{c} \\
(-38)\end{array}$ & $\begin{array}{c}10.80 \mathrm{c} \\
(-55)\end{array}$ & $\begin{array}{l}1.07 \mathrm{c} \\
(-48)\end{array}$ & $\begin{array}{c}0.06 \mathrm{c} \\
(-67)\end{array}$ & $\begin{array}{l}1.13 \mathrm{c} \\
(-49)\end{array}$ & $\begin{array}{c}73.14 \mathrm{~d} \\
(-42)\end{array}$ & $\begin{array}{c}12.98 \mathrm{c} \\
(-41)\end{array}$ & $\begin{array}{c}19.87 \mathrm{bc} \\
(-53)\end{array}$ & $\begin{array}{c}14.93 \mathrm{c} \\
(-58)\end{array}$ & $\begin{array}{c}137.00 \mathrm{bc} \\
(-8)\end{array}$ \\
\hline 100 & $\begin{array}{c}14.84 \mathrm{c} \\
(-43)\end{array}$ & $\begin{array}{c}10.80 \mathrm{c} \\
(-55)\end{array}$ & $\begin{array}{c}0.87 \mathrm{~d} \\
(-58) \\
\end{array}$ & $\begin{array}{c}0.06 \mathrm{c} \\
(-67)\end{array}$ & $\begin{array}{c}0.92 \mathrm{~d} \\
(-59) \\
\end{array}$ & $\begin{array}{c}66.18 \mathrm{e} \\
(-47) \\
\end{array}$ & $\begin{array}{c}11.40 \mathrm{~cd} \\
(-48)\end{array}$ & $\begin{array}{c}20.68 \mathrm{bc} \\
(-51)\end{array}$ & $\begin{array}{c}14.84 \mathrm{c} \\
(-58)\end{array}$ & $\begin{array}{c}135.10 \mathrm{ab} \\
(-9) \\
\end{array}$ \\
\hline LSD P $\leq 0.05$ & 4.09 & 2.62 & 0.18 & 0.03 & 0.18 & 5.47 & 1.73 & 2.83 & 4.22 & 13.81 \\
\hline
\end{tabular}

* Means with different letters differ significantly at the $5 \%$ probability level by an LSD test. ** Figures given in parentheses show the percentage change over the control.

Table 4 - Influence of aqueous wheat extract at different concentrations on chlorophyll, phenolic contents, soluble proteins and antioxidants of horse purslane

\begin{tabular}{|c|c|c|c|c|c|c|}
\hline \multirow{2}{*}{$\begin{array}{c}\text { Aqueous } \\
\text { wheat straw } \\
\text { extract } \\
\text { concentration }\end{array}$} & \multirow[b]{2}{*}{$\begin{array}{c}\text { Total } \\
\text { chlorophyll }\end{array}$} & \multirow[b]{2}{*}{$\begin{array}{c}\text { Total soluble } \\
\text { phenolics }\end{array}$} & \multirow[b]{2}{*}{$\begin{array}{l}\text { Soluble } \\
\text { proteins }\end{array}$} & \multicolumn{3}{|c|}{ Antioxidant enzymes } \\
\hline & & & & CAT & POX & SOD \\
\hline$(\%)$ & \multicolumn{3}{|c|}{$\left(\mathrm{mg} \mathrm{g}^{-1} \mathrm{FW}\right)$} & \multicolumn{2}{|c|}{$\left(\mu \mathrm{mol} \min ^{-1} \mathrm{~g}^{-1}\right.$ protein $)$} & (Units $\mathrm{g}^{-1}$ protein) \\
\hline 0 & $4.11 \mathrm{a}^{*}$ & $1.54 \mathrm{c}$ & $1.62 \mathrm{a}$ & $3.16 \mathrm{~d}$ & $1.67 \mathrm{~b}$ & $43.42 \mathrm{~d}$ \\
\hline 25 & $\begin{array}{c}3.80 \mathrm{ab} \\
(-7)^{* *}\end{array}$ & $\begin{array}{c}1.83 \mathrm{c} \\
(19)\end{array}$ & $\begin{array}{c}1.77 \mathrm{a} \\
(9)\end{array}$ & $\begin{array}{c}5.96 \mathrm{~d} \\
(89)\end{array}$ & $\begin{array}{l}3.40 \mathrm{~b} \\
(103)\end{array}$ & $\begin{array}{c}67.39 \mathrm{bc} \\
(55)\end{array}$ \\
\hline 50 & $\begin{array}{c}3.01 \mathrm{bc} \\
(-27)\end{array}$ & $\begin{array}{c}2.24 \mathrm{bc} \\
(45)\end{array}$ & $\begin{array}{c}0.82 \mathrm{~b} \\
(-49)\end{array}$ & $\begin{array}{c}10.92 \mathrm{c} \\
(245)\end{array}$ & $\begin{array}{l}3.39 \mathrm{~b} \\
(103)\end{array}$ & $\begin{array}{c}74.82 \mathrm{~b} \\
(72)\end{array}$ \\
\hline 75 & $\begin{array}{c}2.45 \mathrm{~cd} \\
(-40)\end{array}$ & $\begin{array}{c}2.72 \mathrm{ab} \\
(77)\end{array}$ & $\begin{array}{c}0.587 \mathrm{~b} \\
(-64)\end{array}$ & $\begin{array}{c}25.33 \mathrm{~b} \\
(101) \\
\end{array}$ & $\begin{array}{l}8.64 \mathrm{a} \\
(417) \\
\end{array}$ & $\begin{array}{c}304.80 \mathrm{a} \\
(602)\end{array}$ \\
\hline 100 & $\begin{array}{c}1.79 \mathrm{~d} \\
(-56)\end{array}$ & $\begin{array}{l}3.16 \mathrm{a} \\
(105)\end{array}$ & $\begin{array}{c}0.44 \mathrm{~b} \\
(-73)\end{array}$ & $\begin{array}{c}29.14 \mathrm{a} \\
(822)\end{array}$ & $\begin{array}{l}9.58 \mathrm{a} \\
(474)\end{array}$ & $\begin{array}{c}50.12 \mathrm{~cd} \\
(15)\end{array}$ \\
\hline LSD $\mathrm{P} \leq 0.05$ & 1.00 & 0.71 & 0.434 & 2.91 & 2.46 & 23.07 \\
\hline
\end{tabular}

* Means with different letters differ significantly at the $5 \%$ probability level by an LSD test. ** Figures given in parentheses show the percentage change over the control.

with higher total phenolics in horse purslane seedling (Figure 2) and regression accounted for $94 \%$ of variation in the chlorophyll content owing to total phenolics. Phytochemicalmediated reduction in seedling photosynthetic pigments primarily due to phenolic acids has also been reported by Inderjit \& Dakshini (1992). Yang et al. (2002) investigated the effects of three phenolic acids on the concentration of chlorophyll and its three biosynthetic porphyrin precursors and showed an inverse relation between their concentration and the phenolic acids. They argued that the tested phenolic acids might have Mg-chelatase, which is an enzyme that is responsible for the conversion of Proto into Mg-Proto as their major target.

Alteration in germination and seedling morphology under phytotoxic stress in the present studies can be attributed to induced oxidative damage and the activation of the cellular anti-oxidant system (Oracz et al., 2007; Bogatek \& Gniazdowska, 2007). Oxidative 


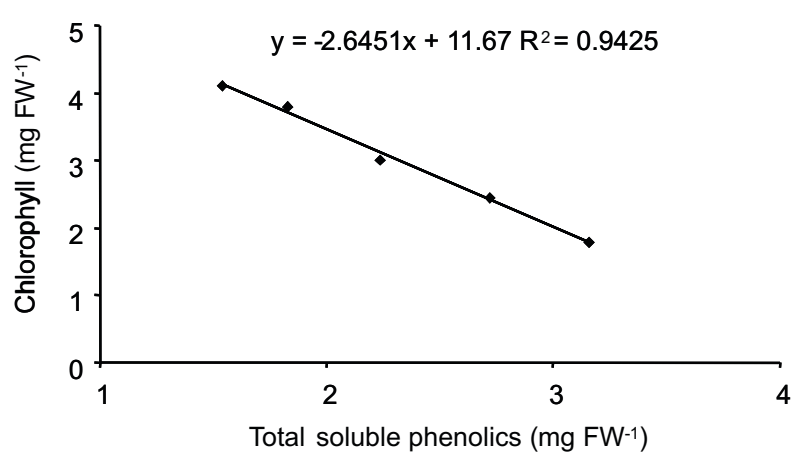

Figure 2 - Relationship between the total soluble phenolics and total chlorophyll content in horse purslane treated with aqueous wheat straw extracts.

stress can alter permeability and fluxes across the plasma membrane causing oxidative burst. Plants tend to overcome this situation by activating enzymes of defense systems, and increased activity of stress enzymes is regarded as a stress marker. SOD, a metallo enzyme, is involved in the detoxification of superoxide radicals (Apel \& Hirt, 2004). Decreased activity of SOD at a higher extract concentration indicated the possible failure of the antioxidant system to cope with oxidative damage. Similar results are reported by Huang et al. (2010). CAT is an antioxidant that prevents $\mathrm{H}_{2} \mathrm{O}_{2}$ accumulation in cells while POX also scavenges $\mathrm{H}_{2} \mathrm{O}_{2}$ and protects cell organelles. Increased expression of CAT and POX under allelopathic stress has also been reported by Niakan \& Mazandrani (2009). The induction and activation of the antioxidant system in treated horse purslane seedlings compared with those of the control suggest the oxidative nature of damage caused by wheat allelochemicals and at the same time implies that horse purslane possess the ability to activate its antioxidant defense upon exposure to allelopathic or possibly any other stress.

The present studies concluded that wheat phytotoxins in aqueous straw extracts inhibited germination and seedling growth of horse purslane, and the inhibition was concentration dependent. Such an inhibition is mediated by the reduction of size of the assimilatory surface, total chlorophyll content, soluble proteins, and enhanced oxidative damage as expressed by the increased activity of antioxidants. It is imperative to conclude that the concentration of these allelochemicals must accumulate under field conditions to affect the individuals of a weed community for their practical implications. Such a phenomenon demands field investigations considering all other factors of the ecology. The role of microbial degradation and soil adsorption complex in enhancing or eliminating the allelopathic effects are important aspects in this regard. The allelopathic inhibition of horse purslane can be explored through the management of wheat straw in different wheatbased cropping systems.

\section{ACKNOWLEDGEMENTS}

The financial support from the Higher Education Commission, Government of Pakistan, under the National Research Program is gratefully acknowledged.

\section{LITERATURE CITED}

APEL, K.; HIRT, H. Reactive oxygen species metabolism, oxidative stress, a signal transduction. Ann. Rev. Plant Biol., v. 55 , n. 1, p. $373-399,2004$

ASSOCIATION OF OFFICIAL SEED ANALYSIS - AOSA. Seed vigor testing handbook. Springfield: 1983

(Contribution, 32)

ASSOCIATION OF OFFICIAL SEED ANALYSIS - AOSA. Rules for testing seeds. J. Seed Technol., v. 12, n. 3, p. 1$112,1990$.

BLUM, U. et al. Evidence for inhibitory allelopathic interactions involving phenolic acids in field soils: concepts vs. experimental model. Crit. Rev. Plant Sci., v. 18, n. 5, p. 673-693, 1999.

BOGATEK, R.; GNIAZDOWSKA. A. ROS and phytohormonees in plant-plant allelopathic interactions. Plant Signaling Behavior, v. 2, n. 4, p. 317-318, 2007.

BHOWMIK, P. C.; INDERJT, B. D. Challenges and opportunities in implementing allelopathy for natural weed management. Crop Protec., v. 22, n. 4, p. 661-671, 2003.

BRADFORD, M. M. A rapid and sensitive method for the quantification of microgram quantities of protein utilizing the principle of protein-dye binding. Annal. Biochem., v. 72, n. 1, p. 248-254, 1976.

CHAVES, N. et al. Plant growth inhibiting flavonoids in exudate of Cistus ladanifer and in associated soils. J. Chem. Ecol., v. 27, n. 3 p. 623-631, 2001. 
CHOU, C. H. Roles of allelopathy in plant biodiversity and sustainable agriculture. Crit. Rev. Plant Sci., v. 18, n. 5, p. 609-636, 1999.

DHINDSA, R. S. et al. Leaf senescence: correlated with increased levels of membrane permeability and lipid peroxidation, and decreased levels of superoxide dismutase and catalase. J. Exper. Bot., v. 32, n. 1, p. 93-101, 1981.

DUKE, S. O.; DAYAN, F.E. Modes of action of phytotoxins from plants. In: REIGOSA, M. J.; PEDROL, N.; GONZÁLEZ, L. (Eds.). Allelopathy: a physiological process with ecological implications. Boston: Kluwer Academic Press, 2006. p. 511-536.

DUKE, S. O. et. al. Allelochemicals as herbicides. In: BONJOCH, N. P.; REIGOSA, M. J. (Eds.) EUROPEAN OECD ALLELOPATHY SYMPOSIUM: Physiological Aspects of Allelopathy, 1., 2001, Vigo. Proccedings... Vigo: GAMESAL, 2001. p. 47-59.

EGLEY, G. H. et al. Role of peroxidase in the development of water impermeable seed coats in Sida spinosa L. Planta, v. 157, n. 3 , p. $224-232,1983$.

ELLIS, R. A.; ROBERTS, E. H. The quantification of ageing and survival in orthodox seeds. Seed Sci. Technol., v. 9, p. $373-409,1981$.

ESCUDERO, A. et al. Inhibitory effects of Artemisia herbaalba on the germination of the gypsophyta Helianthemum squamatum. Plant Ecol., v. 148, n. 1. p. 71-80, 2000.

FAROOQ, M. et al. Thermal hardening: a new seed vigor enhancing tool in rice. J. Integrative Plant Biol., v. 47, n. 2, p. 187-193, 2005.

FREED, R. D.; SCOTT, D. E. MSTATC. Crop and soil. Michigan, Michigan State University, 1986.

GALLANDT, E. et al. Improving soil quality: implications for weed management. J. Crop Produc., v. 2, n. 1, p. 95-121. 1999.

GIANNOPOTITIS, C. N.; RIES, S. K. Superoxide dismuatse I. occurrence in higher plants. Plant Physiol., v. 59, n. 2, p. 309-314, 1977.

HUANG, J. H. et al. Allelopathic effects of cassava (Manihot esculenta crantz.) on radish and rye grass (Lolium perene L.). Allelopathy J., v. 25, n. 1, p. 155-162, 2010.

INDERJT, D.; DAKSHINI, K. M. M. Interference potential of Pluchea lanceolata (Asteraceae): growth and physiological responses of asparagus bean, Vigna unguiculata var. sesquipedalis. Am. J. Bot., v. 79, n. 9, p. 977-981, 1992.

INDERJT, D.; WEINER, J. Plant allelochemical interference or soil chemical ecology? Perspect. Plant Ecol. Evol. System., v. 4, n. 1. p. 3-12, 2001
INDERJIT, D.; WESTON, L. A. Are laboratory bioassays for allelopathy suitable for prediction of field responses? $\mathbf{J}$.

Chem. Ecol., v. 26, n. 9, p. 2111-2118, 2000.

KHALIQ, A. et al. Inhibitory activity of sorghum and sunflower water extracts on germination and seedling growth of Cichorium intybus L. In: INTERNATIONAL CONFERENCE OF ASIAN ALLELOPATHIC SOCIETY, 1 , 2009, Guangzhou. Proceedings... Guangzhou, China: 2009. p. $110-125$

KHANH, T. D. et al. The exploitation of crop allelopathy in sustainable agricultural production. J. Agron.Crop Sci., v. 191, n. 3 , p. 172-184, 2005.

LI, X. J. et al. A preliminary study on allelopathic effect of wheat plant extracts on Digitaria ciliaris (L.) Scop. Weed Sci., v. 3, n. 1, p. 4-6, 2000.

LABBAFI, M. R. et al. Evaluation of allelopathic potential of Iranian wheat (Triticum aestivum L.) cultivars against weeds Agric. Biol. J. North Am., v. 1, n. 3, p. 355-361, 2010.

LICHTENTHALER, H. K.; WELLBURN, A. Chlorophyll and carotenoids: pigments of photosynthetic bio-membranes. In: PACKER, L.; DOUCE, R. (Eds.). Methods in enzymology. San Diego: Academic Press, 1987. p. 350-382.

LIEBL, R. A.; WORSHAM, A. D. Inhibition of pitted morning glory (Ipomoea lacunose L.) and certain other weed species by phytotoxic components of wheat (Triticum aestivum L.) straw. J. Chem. Ecol., v. 9, n. 8, p. 1027-1043, 1983.

LODHI, M. A. et al. Allelopathy in Agroecosytems: Wheat phytotoxicity and its possible roles in crop rotation. J. Chem. Ecol., v. 13, n. 8, p. 1881-1891, 1987.

MA, Y. Q. Allelopathic studies of common wheat (Tritcum aestivum L.). Weed Biol. Manag., v. 5, n. 3, p. 93-104, 2005

MATHIASSEN, S. K. et al. Herbicidal effects of soilincorporated wheat. J. Agric. Food Chem., v. 54, n. 4, p. 1058-1063, 2006.

NIAKAN, M.; MAZANDRANI, N. Allelopathic effects of ascorbic acid and canola on germination and antioxidant activity of soybean. Alleopathy J., v. 24, n. 2, p.283-290, 2009.

ORACZ, K. et al. Induction of oxidative stress by sunflower phytotoxins in germinating mustard seeds. J.Chem. Ecol., v. 33, n. 2 , p. $251-264,2007$

PATTERSON, D. T. Effects of allelochemicals on growth and physiological responses of soybean (Glycine max). Weed Sci., v. 29, n. 1, p. 53-59, 1981. 
RANDHIR, R.; SHETTY, K. Developmental stimulation of total phenolics and related antioxidant activity in light and dark germinated maize by natural elicitors. Process

Biochem., v. 40, n. 5, p. 1721-1732, 2005

STEEL, R. G. D. et al. Principles and procedures of statistics: a biometrical approach. 3.ed. New York: McGraw Hill Book, 1997. p. 172-177.

TESIO, F.; FERRERO, A. Allelopathy, a chance for sustainable weed management. Inter. J. Sustain. Dev. World Ecol., v. 17, n. 5, p. 377-389, 2011.

VILLAGRASA, M. et al. Benzoxazinoid allelochemicals in wheat: Distribution among foliage, roots, and seeds. J. Agric. Food Chem., v. 54, n. 4, p. 1009-1015, 2006

WESTON, L. A.; DUKE, S. O. Weed and crop allelopathy. Crit. Rev. Plant Sci., v. 22, n. 3/4, p. 367-389, 2003

WU, H. et al. Laboratory screening for allelopathic potential of wheat (Triticum aestivum) accessions against annual ryegrass (Lolium rigidum). Austr. J. Agric. Res., v. 51, n. 2, p. $259-266,2000$ b.
WU, H. et al. Allelochemicals in wheat (Triticum aestivum L.) Variation of phenolic acids in shoot tissues. J. Chem. Ecol., v. 27, n. 1, p. $125-135,2001$.

WU, H. et al. Distribution and exudation of allelochemicals in wheat (Triticum aestivum L.). J. Chem. Ecol., v. 26, n. 9, p. 2141-2154, 2000a.

WU, H. et al. Biochemical basis for wheat seedling allelopathy on the suppression of annual ryegrass (Lolium rigidum). J. Agric. Food Chem., v. 50, n. 16, p. 4567-4571, 2002.

XINGXINAG, G. et al. Allelopathic effects of Hemisterpa lyrata on the germination and growth of wheat, sorghum, cucumber, rape and radish seeds. Weed Biol. Manag., v. 9, n. 3, p. 243-249, 2009.

YANG, C. M. et al. Effects of three allelopathic phenolics on chlorophyll accumulation of rice (Oryza sativa) seedlings: I. Inhibition of supply-orientation. Bot. Bull. Academia Sinica, v. 43, n. 4, p. 299-304, 2002. 